\title{
ASPEK ERGONOMI AKTIVITAS PENANGKAPAN IKAN TUNA PADA KAPAL LONGLINE KM SATELIT, DI MUARA BARU, JAKARTA UTARA
}

\author{
Ergonomic Aspecs of Tuna Fishing Activities on A Longliner MV Satelit, In Muara Baru, \\ Jakarta \\ Oleh: \\ Maria Putri Widhyasari1, Vita Rumanti Kurniawati², Budhi Hascaryo Iskandar ${ }^{3}$
${ }^{1}$ Yatch Sourcing Indonesia. mariapw@gmail.com
2Departemen Pemanfaatan Sumberdaya Perikanan, Fakultas Perikanan dan Ilmu Kelautan, Institut Pertanian Bogor vitarumanti@apps.ipb.ac.id
${ }^{3}$ Departemen Pemanfaatan Sumberdaya Perikanan, Fakultas Perikanan dan Ilmu Kelautan, Institut Pertanian Bogor bhascaryo.iskandar@gmail.com

*Korespondensi:vitarumanti@apps.ipb.ac.id

\begin{abstract}
This research was aiming at analysing ergonomic aspects and identifying potential hazards resulted from fishing activities. Data was collected from a long line fishing vessel MV Satelit. Analysis of ergonomic aspects focused on four major activities namely setting, drifting, hauling and fish handling. The investigation was conducted to examine the suitability of on board working area with fishermen's movement. The result showed that on board working area was inadequate compared to fishermen's movement because of limited zones for fishermen (ranged from $1-3 \mathrm{~m} 2 /$ person) without any safety equipment. Based on Job Safety Analysis (JSA), it was revealed that there were 14 potential hazards emerging from fishing activities; $64,29 \%$ of them were moderate risk and the rest were trivial risk. However, fishermen have no significant efforts to prevent those hazards.
\end{abstract}

Keywords: : ergonomic, fishing vessel, occupational health and safety, tuna fishing, potential hazards

\begin{abstract}
ABSTRAK
Penelitian ini bertujuan untuk mendeskripsikan aspek ergonomi pada kapal long line dan mengidentifikasi potensi bahaya yang timbul dari aktivitas penangkapan ikan. Penelitian ini merupakan penelitian analisa kerja dan aktivitas dengan objek kapal longline KM Satelit. Aktivitas di atas KM. Satelit yang akan dikaji dalam penelitian ini meliputi setting, drifting, hauling, dan penanganan hasil tangkapan. Pengkajian aspek ergonomi pada aktivitas penangkapan tuna ditekankan pada kesesuaian area kerja di atas kapal dengan aktivitas anak buah kapal (ABK) selama operasi penangkapan ikan berlangsung. Hasil penelitian menunjukkan bahwa area kerja di atas kapal masih belum memadai karena ruang gerak ABK terbatas antara $1-3 \mathrm{~m}^{2} /$ orang dan tanpa pengamanan. Sementara itu, hasil analisis dengan menggunakan Job Safety Analysis (JSA) menunjukkan bahwa terdapat 14 potensi bahaya yang timbul dari aktivitas penangkapan; $64,29 \%$ dari potensi bahaya tersebut masuk dalam kategori risiko sedang dan sisanya kategori risiko rendah. Hasil wawancara dengan ABK dan observasi lapang menunjukkan bahwa upaya pencegahan yang dilakukan masih sederhana.
\end{abstract}

Kata kunci: ergonomi, kapal perikanan, keselamatan kerja, penangkapan tuna, potensi bahaya 


\section{PENDAHULUAN}

Operasi penangkapan ikan merupakan kegiatan yang cukup berisiko karena berbagai potensi bahaya yang dihadapi, seperti kondisi laut yang tidak menentu dan kecelakaan kerja di atas kapal. Selain itu, penggunaan berbagai macam alat bantu penangkapan, peralatan keselamatan yang minim, dan kelelahan Anak Buah Kapal (ABK) juga semakin memperbesar potensi bahaya yang dihadapi. Bahkan menurut Hutauruk et al. (2011) kapal perikanan merupakan penyumbang tertinggi dalam angka kecelakaan kapal di laut. Hal tersebut dipertegas oleh Suwardjo et al. (2010) yang menyebutkan bahwa Fatality Accident Rate (FAR) untuk kapal penangkap ikan di tiga pelabuhan perikanan di Indonesia adalah 115, yang artinya 115/100.000 orang hilang/meninggal di laut. Angka tersebut jauh lebih tinggi dibandingkan dengan FAR untuk kapal penangkap ikan dunia, yaitu 80 . Selain potensi bahaya yang tinggi, bekerja di atas kapal penangkap ikan juga identik dengan lingkungan kerja yang tidak nyaman karena terbatasnya area kerja dan akomodasi di atas kapal (Marshall et al. 2004).

Ergonomi adalah cabang ilmu yang secara sistematis memanfaatkan informasiinformasi mengenai sifat, kemampuan dan keterbatasan manusia untuk merancang suatu sistem kerja yang lebih baik (Wilson 2000). Deouskar (2017) mengungkapkan bahwa aplikasi ergonomi dapat meningkatkan produktivitas dan kualitas kerja manusia. Lebih jauh, Bayram et al. (2016) juga mengemukakan bahwa aplikasi ergonomi dapat menurunkan kecelakaan dan penyakit akibat kerja.

Dalam kegiatan operasi penangkapan ikan, ergonomi erat kaitannya dengan kenyamanan dan keselamatan kerja di atas kapal. Kenyamanan adalah suatu kondisi telah terpenuhinya kebutuhan dasar klien yang meliputi ketentraman, kelegaan dan transenden (Kolcaba 1992). Sementara itu, menurut Kamus Besar Bahasa Indonesia, keselamatan adalah suatu kondisi yang terhindar dari bahaya. Oleh karena itu, penerapan ergonomi di kapal penangkap ikan perlu dipertimbangkan sebagai upaya untuk meningkatkan kenyamanan dan keselamatan kerja ABK.

Kajian tentang ergonomi kapal, khususnya kapal penangkap ikan sudah mulai dilakukan pada beberapa tahun terakhir ini. Beberapa di antaranya memberikan berbagai informasi terkait aspek ergonomi yang perlu diperhatikan dalam mendesain maupun mengoperasikan kapal dan alat tangkap, seperti pada aktivitas penangkapan ikan dengan kapal pancing ulur (Basya et al. 2017), kapal payang (Soeboer et al.
2018), kapal bubu lobster (Duguid dan Vosper 2019). Selain itu, terdapat juga penelitian yang fokus pada kesehatan dan keselamatan nelayan sebagai akibat dari lingkungan kerja yang terbatas, seperti yang dilakukan oleh Mansi et al. (2019) dan Dharmawirawan dan Modjo (2012).

Salah satu kegiatan penangkapan ikan yang cukup berisiko namun menghasilkan komoditas perikanan unggulan adalah penangkapan tuna menggunakan longline. Kegiatan penangkapan ini terkonsentrasi di atas dek kapal yang terbatas $( \pm 30 \%$ dari keseluruhan dek kapal), mempunyai ritme kerja yang cepat (terutama pada saat Setting dan hauling), dan melibatkan alat bantu penangkapan yang berbahaya, seperti line hauler, line thrower dan branch reel. Selain itu, kapal longline umumnya beroperasi antara 2 sampai 7 bulan dan jumlah Anak Buah Kapal (ABK) lebih dari 10 orang. Dalam waktu operasi yang lama dan lingkungan kerja yang terbatas tersebut, ABK kapal longline dituntut untuk memiliki produktivitas kerja yang tinggi. Sementara itu, terbatasnya lingkungan kerja di kapal akan menimbulkan ganguan fisik yang dapat berpengaruh pada produktivitas kerja ABK (Fulmer et al. 2002; Marshall et al., 2004) yang juga berpotensi menyebabkan kecelakaan kerja di kapal (Basya et al. 2017; Soebeor et al. 2018). Berdasarkan hal tersebut, lingkungan kerja di atas kapal longline perlu di desain dengan mempertimbang aspek ergonomi dengan harapan dapat meningkatkan produktivitas dan keselamatan kerja ABK.

Namun, untuk dapat menciptakan lingkungan kerja yang ergonomis, hal-hal yang berkaitan dengan aktivitas kerja di atas kapal perlu dikaji terlebih dahulu. Berdasarkan hasil telaah pustaka, belum banyak kajian yang fokus pada kapal tuna maupun aktivitas penangkapannya. Oleh karena itu, tujuan dari penelitian ini adalah mendeskripsikan aspek ergonomi dan mengidentifikasi potensi bahaya yang timbul dari aktivitas penangkapan ikan di atas kapal longline. Penelitian ini merupakan penelitian awal tentang aspek ergonomi pada kapal longline, sehingga masih terbatas pada kajian deskriptif mengenai kondisi lingkungan kerja di atas kapal dan persepsi ABK terhadap kondisi tersebut. Harapannya, setelah penelitian ini akan banyak dilakukan penelitian-penelitian lanjutan sebagai upaya untuk meningkatkan kenyamanan, keselamatan dan produktivitas kerja $\mathrm{ABK}$ di atas kapal longline.

\section{METODE}

Penelitian ini merupakan penelitian analisa kerja dan aktivitas dengan objek kapal long line KM Satelit yang sedang bersandar di 
Pelabuhan Perikanan Nusantara Nizam Zachman (PPSNZ), Muara Baru Jakarta Utara. Penelitian dilakukan pada bulan Mei 2016 di Dermaga Timur, PPSNZ. Metode analisis data yang digunakan adalah metode deskriptif menggunakan matriks Job Safety Analysis (JSA). Metode JSA digunakan untuk mengidentifikasi, menganalisis dan mencatat tahapan pekerjaan, potensi bahaya pada setiap tahap, dan tindakan yang disarankan untuk menghilangkan/mengurangi potensi bahaya (Martino et al. 2002).

Data tentang aktivitas dan peralatan yang digunakan selama kegiatan penangkapan ikan berlangsung diperoleh melalui observasi, pengu-kuran langsung dimensi peralatan yang digunakan ABK, pendokumentasian bagianbagian kapal KM Satelit dan wawancara mendalam (deep interview) dengan semua ABK kapal tersebut. Jenis data yang dikumpulkan meliputi 1) data aktivitas selama operasi penangkapan ikan; 2) posisi ABK saat bertugas; 3) jenis, ukuran dan posisi alat bantu; 4) general arrangement kapal; dan 5) pengalaman ABK selama bekerja di kapal tersebut. Data yang diperoleh dari lapangan selanjutnya dianalisis dengan JSA (Tabel 1). Penentuan tingkat risiko dari tiap potensi bahaya yang teridentifikasi dilakukan dengan matriks penilaian risiko menurut Tarwaka (2008) seperti yang dapat dilihat pada Tabel 2 .

Tabel 1 Lembar Kerja JSA

\begin{tabular}{lccc}
\hline No & Urutan Kegiatan & Potensi Bahaya & $\begin{array}{c}\text { Tindakan } \\
\text { Pencegahan }\end{array}$ \\
\hline $\mathbf{1}$ & Kegiatan ke-1 & $\ldots$ & $\ldots$ \\
$\ldots$ & $\ldots$ & $\ldots$ & $\ldots$ \\
$\mathbf{n}$ & Kegiatan ke-n & $\ldots$ & $\ldots$ \\
\hline
\end{tabular}

Tabel 2 Matriks Penilaian Risiko

\begin{tabular}{lcccc}
\hline \multicolumn{1}{c}{ Konsekuensi } & \multicolumn{2}{c}{ Kemungkinan } \\
& Sering (4) & Agak Sering (3) & Jarang (2) & Jarang sekali (1) \\
\cline { 2 - 4 } Bencana (5) & Mendesak (20) & Mendesak (15) & Tinggi (10) & Sedang (5) \\
Fatal (4) & Mendesak (16) & Tinggi (12) & Sedang (8) & Rendah (4) \\
Cedera Berat (3) & Tinggi (12) & Sedang (9) & Sedang (6) & Rendah (3) \\
Cedera Ringan (2) & Sedang (8) & Sedang (6) & Rendah (4) & Rendah (2) \\
Hampir Cedera (1) & Rendah (4) & Rendah (3) & Rendah (2) & Tidak ada (1) \\
\hline
\end{tabular}

Sumber: Tarwaka (2008)

\section{HASIL}

\section{Gambaran Umum KM Satelit}

KM Satelit merupakan kapal penangkap tuna berukuran 60 GT. Spesifikasi kapal tersebut dapat dilihat pada Tabel 3 . Kapal dengan spesifikasi ini merupakan kapal penangkap tuna yang paling banyak digunakan oleh perusahaan penangkapan ikan di PPSNZ Jakarta. Sementara itu, general arrangementnya sepertinya yang diilustrasikan pada Gambar 1.

Kapal ini melakukan trip penangkapan selama 7 bulan dengan 5 bulan efektif operasi. Waktu yang diperlukan untuk perjalanan menuju dan berpindah ke fishing ground lain masing-masing selama \pm 3 hari. Tiap harinya dilakukan setting pada pukul 6.00 - 12.00, drifting pada pukul 12.00 - 18.00 dan hauling pada pukul 18.00-02.00. Operasi penangkapan dilakukan setiap hari kecuali pada hari jumat.

Luas dek utama kapal ini kurang lebih $134 \mathrm{~m}^{2}$, dari luasan tersebut $15 \mathrm{~m}^{2}(11,2 \%)$ merupakan area kerja untuk setting yang terletak di bagian buritan kapal, dan $45 \mathrm{~m}^{2}$ $(33,6 \%)$ merupakan area kerja untuk hauling dan penanganan ikan yang terletak di bagian haluan kapal. Selain dek, area lain yang digunakan untuk aktivitas $\mathrm{ABK}$ adalah ruang istirahat yang menyatu dengan ruang kemudi dan terletak di bagian tengah kapal, ruang mesin yang terletak di bawah dek kapal, serta dapur yang terletak di bagian buritan.

Sebagai area kerja utama, di dek kapal terdapat alat bantu penangkapan yang terdiri atas, line hauler, side roller, ganco, dan radio 
buoy. Sementara itu, alat bantu navigasi seperti kompas, radio direction finder (RDF), GPS, dan peta terkonsentrasi di ruang kemudi.

\section{Aktivitas di Atas Kapal}

Operasi penangkapan ikan tuna menggunakan alat tangkap tuna longline dibagi menjadi beberapa kegiatan yaitu setting, drifting, hauling, dan penanganan hasil tangkapan. Setting alat tangkap dilakukan di buritan. Di bagian ini terdapat radio buoy, blong/wadah untuk branch line dan main line, bak untuk umpan dan meja setting. Selanjutnya, pada tahap drifting, ABK beristirahat di wheel house dimana ruang kemudi juga terletak di dalamnya. Setelah drifting selama \pm 6 jam, tahapan hauling dilakukan di bagian haluan kapal. Untuk membantu proses hauling, di bagian ini terdapat berbagai alat bantu seperti line hauler, side roller dan ganco. Kegiatan penanganan hasil tangkapan juga dilakukan di haluan kapal. Pemetaan area-area kerja tersebut di atas kapal dapat dilihat pada Gambar 2. Sementara itu, pada Tabel 4 dapat dilihat tugas spesifik ke-16 ABK selama operasi penangkapan ikan berlangsung.

Sebelum setting dilakukan, ABK terlebih dahulu mempersiapkan alat tangkap. Pada proses ini, ABK yang akan melakukan setting menyiapkan perlengkapan setting yang mencakup 1) pancing dan snap; 2) branch line; 3) main line; 4) umpan; dan 5) radio buoy dan pelampung. Selain itu, mereka juga menempatkan diri pada posisinya masing-masing sesuai dengan tugas yang telah disepakati.

Setting dilakukan selama 6 jam, untuk itu, kapten membagi seluruh ABK menjadi dua shift dan pergantian shiftnya dilakukan setiap \pm 3 jam. Kapal berada pada kecepatan yang cukup rendah, antara 2-5 knot, hal tersebut dilakukan untuk mengurangi ketegangan tali sehingga branch line tetap berada diposisinya dan tidak terbelit. Saat setting, pertama-tama pelampung dan pelampung tanda (pelampung dengan tiang dan bendera) diturunkan beserta dengan tali pelampung. Kemudian, diikuti dengan main line dan branch line beserta mata pancing yang sudah dikaitkan dengan umpannya. Begitu seterusnya, sampai main line dalam satu blong habis, kemudian disambungkan dengan tali utama berikutnya dari blong kedua menggunakan tali penyambung.
Dalam 1 shift, setting dilakukan oleh 5 orang, dengan rincian tugas sebagai berikut:

ABK ke-1: Pemasang umpan dan pelempar branch line.

ABK ke-2: Pemasang snap atau penjepit dari tali cabang dan tali pelampung ke main line sekaligus melempar pelampung.

ABK ke-3: Penaruh umpan dan mata kail, menyiapkan umpan dan kebutuhan teman lainnya.

ABK ke-4: Penyusun tali cabang dan tali pelampung, menyiapkan pelampung.

ABK ke-5: Pemasang dan penyambung pelampung radio buoy dan light buoy pada main line sekaligus melemparkannya.

Setelah setting selesai, kegiatan selanjutnya adalah drifting, yang dilakukan selama 4-6 jam. Pada saat itu, ABK beristirahat di wheel house. Namun, beberapa ABK diharuskan berjaga untuk menjaga longline yang sedang dioperasikan menggunakan Radio Direction Finder (RDF).

Proses selanjutnya adalah hauling. Hauling diawali dengan menaikkan pelampung tanda, radio buoy, tali pelampung dan pemberat ke atas dek kapal. Kemudian dilanjutkan dengan penarikan main line dan branch line. Branch line yang mata pancingnya termakan ikan akan ditarik ke sisi kapal sebelah kanan (starboard), dimana terdapat pintu untuk memasukkan ikan ke dek kapal. Penarikan dilakukan oleh 3 orang atau lebih tergantung ukuran ikan yang tertangkap. Ikan ditarik ke dek kapal dengan bantuan ganco. Sementara itu, branch line yang tidak termakan oleh ikan langsung digulung dan disusun ke dalam bak-bak branch line.

Sama halnya dengan setting, hauling juga dilakukan oleh 5 orang dalam 1 shift, dengan pembagian tugas sebagai berikut:

ABK ke-1: Atau yang disebut bossmen bertugas menjaga handle keran hidraulik line hauler dan melepaskan snap dari tali utama.

ABK ke-2: Menjaga main line pada blong agar tergulung sempurna, mengawasi bila main line putus atau kusut.

ABK ke-3: Menggulung tali cabang dan menyusunnya di bak branch line.

ABK ke-4: Mengambil dan merapikan pelampung, kemudian menaruh ke 
tempat penyimpanan dan membantu penanganan ikan.

ABK ke-5: Membantu memperbaiki kekusutan main line atau branch line.

ABK yang tidak mendapat giliran tugas biasanya membantu memperbaiki branch line yang kusut karena kegiatan tersebut agak sulit dilakukan dan memakan waktu.

Setelah seluruh rangkaian setting, drifting dan hauling dilakukan, kegiatan selanjutnya adalah penanganan hasil tangkapan. Ikan yang telah berhasil ditarik ke dek kapal, diarahkan ke area penanganan yang ada di depan wheel house. Penanganan melibatkan 2 orang $A B K$, dimana ABK 1 menahan ikan menggunakan kedua kakinya untuk menjepit kepala ikan dan ABK 2 memegang badan ikan. ABK 1 menancapkan sebuah paku pembunuh sepanjang $\pm 15 \mathrm{~cm}$ ke pusat syaraf otak di belakang mata sedalam $5-10 \mathrm{~cm}$, sehingga ikan lebih cepat mati dan dapat segera didinginkan. Sebelum didinginkan, insang, isi perut dan kotoran dibuang kemudian ikan disiram dan disikat dengan sikat lembut. Lendir yang menempel di kulit juga harus dibersihkan mengunakan sikat yang lebih lunak. Setelah bersih, ikan tersebut dimasukkan ke dalam palka. Setelah keseluruhan rangkaian kegiatan operasi penangkapan ikan selesai, seluruh ABK diberikan waktu istirahat sampai tiba saatnya untuk setting kembali. Jika hasil tangkapan sedang banyak, mereka bahkan tidak tidur sampai saatnya setting kembali sehingga istirahat hanya dilakukan pada saat drifting.

Tabel 3 Spesifikasi KM Satelit

\begin{tabular}{lllll}
\hline No & Spesifikasi & Ukuran & Satuan & Keterangan \\
\hline 1 & Panjang (LOA) & 26,25 & Meter & - \\
2 & Lebar (B) & 6 & Meter & - \\
3 & Dalam (D) & 5 & Meter & - \\
4 & Draft (d) & 4 & Meter & - \\
5 & Kecepatan & $8-10$ & Knot & - \\
6 & ABK & 16 & Orang & - \\
7 & Gross tonnage & 60 & GT & - \\
8 & Mesin utama & 180 & PK & Nissan RE \\
9 & Mesin bantu & $22 / 2 \times 75$ & PK / KVA & Mitsubisi \\
10 & Palka (p $\times \mathrm{I} \times \mathrm{t})$ & $3 \times 3 \times 4$ & Meter & 4 buah \\
& & $3 \times 3 \times 2$ & & 1 buah \\
\hline
\end{tabular}

Tabel 4 Daftar ABK KM Satelit

\begin{tabular}{lcl}
\hline Posisi & Jumlah & Tugas \\
\hline Kapten/ Nahkoda & 1 & Mengemudikan kapal \\
Wakil kapten & 1 & Mengemudikan kapal dan membantu bosmen \\
Juru lapangan/ Bossmen & 2 & Mengatur kerja di atas kapal \\
Juru mesin/ KKM/ Enginer & 3 & Menjaga mesin tetap bekerja dengan baik \\
Juru masak/ Koki & 2 & Memasak makanan untuk ABK \\
Juru palka/ Kamar dingin & 3 & Mengatur keseluruhan di palka \\
ABK & 6 & Melempar dan menggulung branch line dan main \\
& & line \\
\hline
\end{tabular}



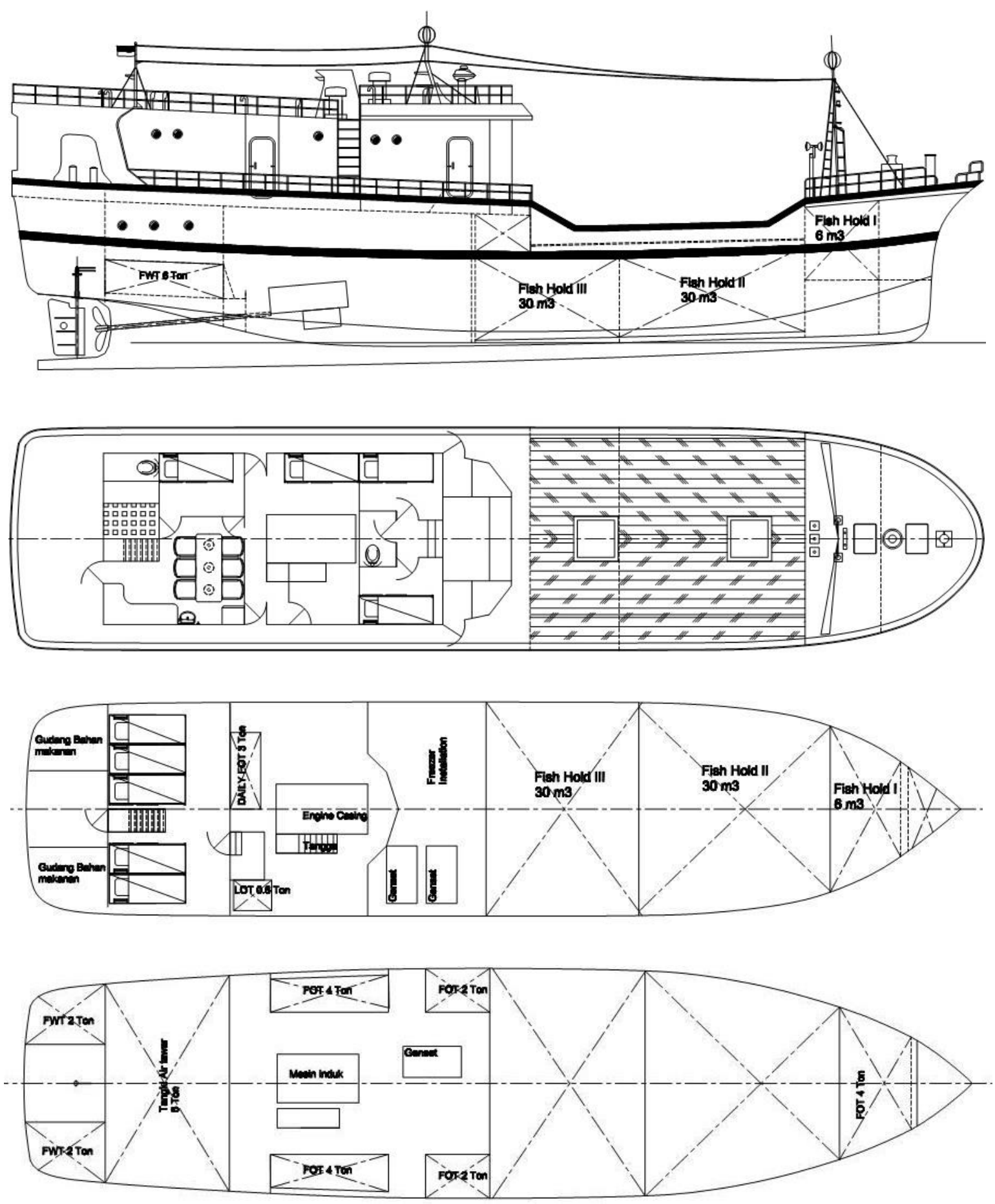

Gambar 1 General arrangement KM Satelit (non skala) 


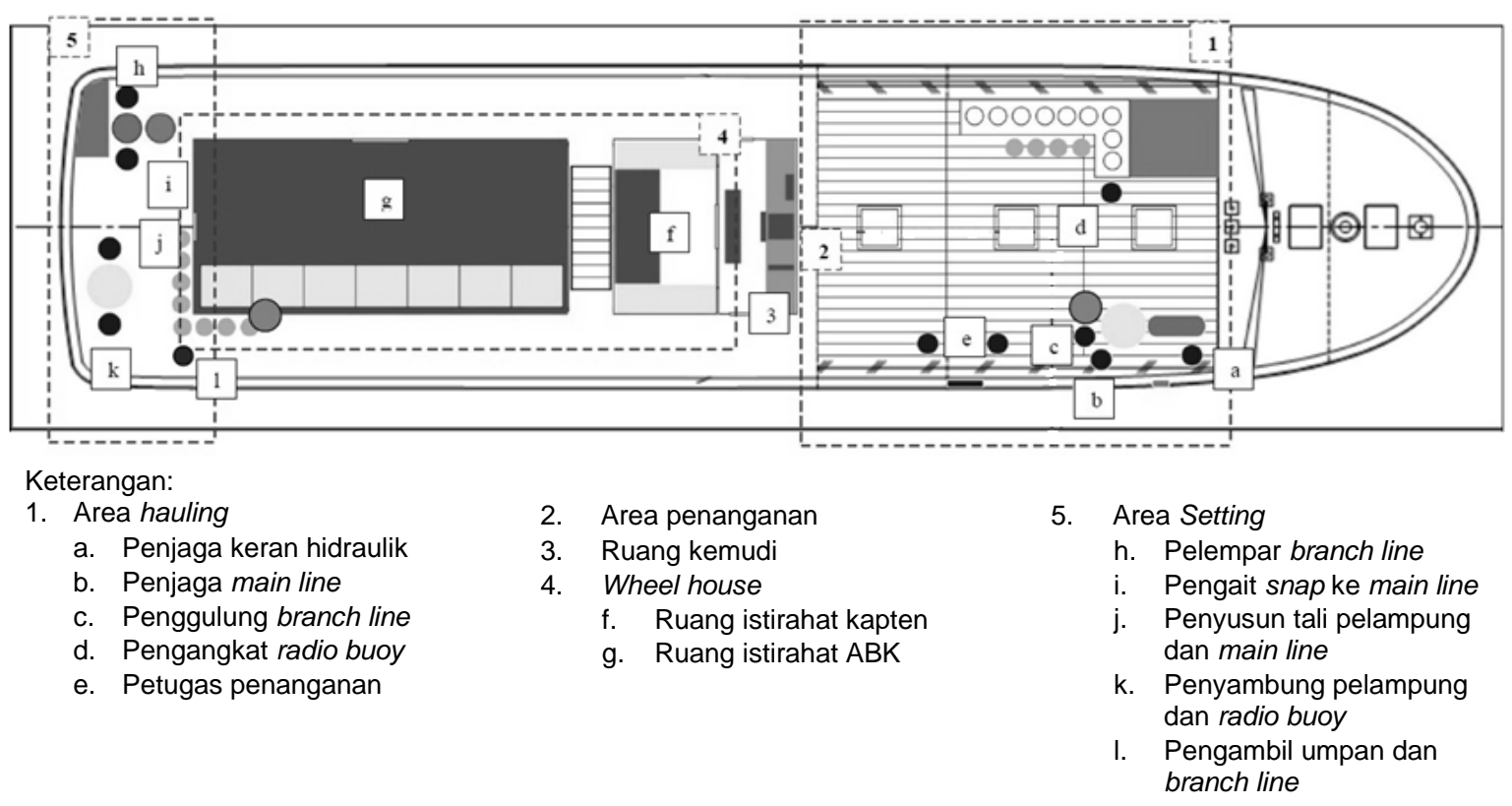

Gambar 2 Pemetaan posisi alat tangkap, alat bantu dan area kerja di dek kapal tampak atas.

\section{Aspek Kenyamanan Kerja di Atas Kapal}

Aspek kenyamanan kerja dilihat dari aktivitas yang dilakukan, ABK yang terlibat dan area atau peralatan yang digunakan selama aktivitas tersebut berlangsung. Untuk mempermudah, dalam penelitian ini kajian ergonomi dilakukan dalam 7 area kerja, yaitu: area setting, area hauling, area penanganan ikan, ruang kemudi, ruang istirahat, ruang mesin, dan dapur.

\section{1) Area setting}

Setting dilakukan dengan cara manual di bagian buritan oleh 5 orang ABK. Luas area kerja yang digunakan untuk setting sekitar $2 \times 6 \mathrm{~m}^{2}\left(12 \mathrm{~m}^{2}\right)$. Di area tersebut terdapat beberapa peralatan setting seperti meja umpan, bak branch line, snap, bak main line, dan pelampung, sehingga dengan adanya peralatan tersebut, area yang tersisa untuk lalu lalang ABK hanya sekitar $8 \mathrm{~m}^{2}$. Area tersebut tergolong sempit jika ditinjau dari jumlah ABK yang bekerja (luasan area kerja 1,6 m²/ orang)

Pada saat setting, ABK yang bertugas memasang umpan dan melempar branch line harus berulang kali membungkuk dan menegakkan badan untuk mengambil branch line dan kemudian melemparkannya. Demikian juga dengan ABK yang bertugas untuk mengaitkan branch line pada main line karena harus mengambil snap yang terletak di lantai dek.
Menurut ABK, keluhan yang mereka rasakan karena aktivitas ini adalah pegal pada pinggang. Hal ini didukung oleh Samara et al. (2005), yang mengemukakan bahwa aktivitas membungkuk berulangulang berisiko mengakibatkan sakit pada pinggang bagian bawah. Sementara itu, pada aktivitas pelemparan branch line, keluhan yang paling dirasakan adalah pegal-pegal di bagian lengan, karena ABK harus melemparkan branch line dengan satu tangan secara berulang-ulang selama 3 jam. Keberadaan alat bantu seperti meja untuk branch line dan snap serta line thrower untuk melempar-kan branch line akan sangat mengurangi tingkat kelelahan dan risiko gangguan kesehatan dari aktivitas ini.

Aktivitas setting juga melibatkan kegiatan pengangkatan beban yang cukup berat. Pertama, pengangkatan bak main line berdiameter $0,8 \mathrm{~m}$ dan tinggi $1 \mathrm{~m}$ yang mengharuskan dilakukan oleh 2 orang. Kedua, pengangkatan dan pelemparan pelampung yang beratnya mencapai $12 \mathrm{~kg}$. Namun, karena jumlahnya yang sedikit, selama setting frekuensi pengangkatan beban ini tidaklah terlalu sering $( \pm 6$ buah/jam).

\section{2) Area hauling}

Hauling juga dilakukan oleh 5 orang, di bagian haluan yang luas areanya $7 \times 6 \mathrm{~m}$ $\left(42 \mathrm{~m}^{2}\right)$. Meskipun areanya cukup luas, kegiatan hauling hanya terkonsentrasi di sisi 
kanan kapal (starboard) yang luasnya kurang lebih $15 \mathrm{~m}^{2}$ (3 $\mathrm{m}^{2} /$ orang). Sisanya digunakan untuk penanganan hasil tangkapan, penyimpanan pelampung dan penempatan tangki air bersih.

Alat bantu yang ada di area hauling adalah line hauler yang berfungsi untuk membantu penarikan main line. Penggunaannya sangat mudah yaitu dengan membuka dan menutup keran hidraulik. Selain itu, tersedia juga branch line ace yang digunakan untuk memudahkan penggulungan branch line. Penggulungan branch line dilakukan oleh ABK dengan cepat, gerakan tersebut berisiko menyebabkan pergelangan tangan terkilir dan terkena mata pancing. Meskipun demikian, untuk melakukan pekerjaan ini, ABK tidak menggunakan sarung tangan sebagai alat pelindung.

Aktivitas hauling juga melibatkan kegiatan pengangkatan beban berat, mengingat berat ikan tuna yang tertangkap bisa mencapai $50 \mathrm{~kg}$. Penarikan ikan ke dek kapal dilakukan oleh 1 - 3 orang tergantung pada ukuran ikan. Pada kondisi dek kapal yang basah dan licin, pengangkatan beban yang berat dapat menimbulkan risiko terpeleset. Untuk mengantisipasi hal itu, ABK memakai sepatu boot bersol kasar selama operasi penangkapan ikan berlangsung.

\section{3) Area penanganan ikan}

Area kerja untuk kegiatan ini kurang lebih $6 \mathrm{~m}^{2}$, berada di dekat area hauling dan di area tersebut penanganan ikan dilakukan oleh 2 orang (luasan area kerja $3 \mathrm{~m}^{2}$ ). Keduanya diharuskan bekerja dengan ritme yang cepat dan menggunakan benda tajam seperti pisau dan paku pembunuh. Meskipun demikian, ABK yang bertugas tidak menggunakan sarung tangan maupun baju pelindung. Hal tersebut sangat berbahaya mengingat badan ikan yang sangat licin dan beberapa diantaranya bahkan masih dalam keadaan hidup.

\section{4) Ruang kemudi}

Ruang kemudi merupakan ruang kerja kapten kapal dengan luas $3 \times 1,2 \mathrm{~m}$ $\left(5,6 \mathrm{~m}^{2}\right)$. Di dalam ruang kemudi terdapat kemudi, kursi kapten, dan peralatan navigasi. Kemudi berdiameter $40 \mathrm{~cm}$, berbahan dasar kayu dan memiliki pegangan berukuran $10 \mathrm{~cm}$ yang bentuknya sesuai dengan genggaman tangan. Di belakang kemudi terdapat kursi kemudi yang berbahan kayu, tanpa sandaran dan dapat dipindah-pindahkan. Kursi tersebut memiliki dimensi $100 \times 20 \times 80 \mathrm{~cm}$. Secara ergonomi kursi tersebut tidak sesuai untuk kapten yang memiliki tinggi badan $167 \mathrm{~cm}$, karena kursi terlalu tinggi dan sempit untuk menopang paha. Hal tersebut dapat mengakibatkan paha tertekan, peredaran darah lambat, melemahnya stabilitas tubuh dan terjatuh atau terjungkal dari kursi (Manuaba 2003). Sementara itu, material yang terbuat dari kayu membuat kapten mudah lelah ketika harus duduk dalam waktu yang cukup lama dan tanpa sandaran belakang, sehingga sering kali kapten mengeluhkan sakit pinggang.

Jarak antara kemudi dan kursi adalah $30 \mathrm{~cm}$, jarak tersebut sudah sesuai dengan postur kapten karena kapten tidak perlu membungkuk untuk mencapai kemudi (posisi arm bellow shoulder). Posisi tangan adalah arm bellow shoulder yang merupakan posisi yang baik karena tidak cepat menimbulkan lelah (Wignjosoebroto 2000). Di sebelah kanan kemudi, terdapat kompas serta persneling dan gas. Posisi kompas memungkinkan kapten melihatnya dengan mudah dari tempat duduk tanpa harus berpindah maupun berdiri. Melihat kompas dilakukan dengan cara menundukkan leher melebihi sudut $30^{\circ}$. Secara ergonomi, hal tersebut masih diperbolehkan selama tidak dilakukan lebih dari 2 jam karena akan mengakibatkan sakit pada leher dan tulang belakang (Manuaba 2003).

Kapten juga dapat menjangkau perseneling dan gas dengan mudah dengan cara menggerakan tangan tanpa memindahkan posisi tubuh sehingga posisi tangan adalah arm by side elbow at $90^{\circ}$. Menurut Wignjosoebroto (2000) posisi tersebut merupakan posisi lengan terhadap siku yang paling baik karena memiliki beban statik minimal.

GPS sebagai alat navigasi berada sisi kiri atas kapten dan mengharuskannya berdiri untuk menjangkaunya. Namun, GPS tidak terlalu sering digunakan karena menggunakan sistem autopilot, sehingga posisinya yang agak jauh dari kapten tidak terlalu mempengaruhi kinerjanya.

5) Ruang istirahat

Dalam operasi penangkapan ikan diterapkan sistem istirahat pendek dan 
istirahat aktif. Istirahat pendek dilakukan pada pergantian shift saat Setting dan hauling masing-masing \pm 3 jam. Istirahat pendek juga dilakukan pada saat drifting. Sementara itu, istirahat aktif merupakan istirahat pada saat menunggu Setting berikutnya yang lamanya \pm 6 jam.

Kapten dan ABK memiliki ruang istirahat yang berbeda. Kapten beristirahat di ruangan dengan luas $3 \times 2 \mathrm{~m}$. Ruangan tersebut dilengkapi dengan tempat tidur berbahan kayu berukuran $180 \times 80 \times 55 \mathrm{~cm}$ dan dilengkapi dengan busa setebal $6 \mathrm{~cm}$. Sementara itu, ruang istirahat $A B K$ merupakan ruangan 2 lantai beralaskan kayu, masing-masing lantai luasnya $6 \times 2 \mathrm{~m}$ dengan tinggi $1 \mathrm{~m}$. Tiap lantai digunakan untuk 6 - 7 ABK. Material yang terbuat dari kayu menyebabkan gesekan yang cukup besar antara tulang punggung dan lantai tidur. Hal ini dapat berakibat fatal dalam jangka panjang, yaitu kelainan tulang belakang (Manuaba 2003). Selain itu, ruangan yang tingginya hanya $1 \mathrm{~m}$ tidak memungkinkan ABK untuk berdiri atau bebas bergerak.

\section{6) Ruang mesin}

Ruang mesin memiliki luas $7 \times 6 \mathrm{~m}$. Juru mesin yang bertugas di dalam kamar mesin adalah 3 orang, 2 orang menjaga mesin utama dan mesin bantu, sedangkan 1 orang lainnya menjaga instalasi refrigerator. Kebisingan akibat suara mesin kapal dan asap yang dikeluarkan sangat menganggu kerja juru mesin. Apalagi mereka harus berada di dalam ruang mesin lebih dari 4 jam per hari. Mereka bahkan tidak menggunakan ear plug, masker dan wear pack di dalam kamar mesin untuk meminimalisir kemungkinan rusaknya fungsi pendengaran, keracunan gas karbon dan bahaya kebakaran dalam kamar mesin.

\section{Aspek Keselamatan Kerja}

Aspek keselamatan kerja dalam
penelitian ini berhubungan dengan
lingkungan kerja yang aman bagi ABK saat
bekerja di atas kapal. Dengan demikian, hal
ini erat kaitannya dengan bahaya yang mungkin timbul ketika operasi penangkapan ikan berlangsung. Bahaya adalah segala hal atau sesuatu yang mempunyai kemungkinan mengakibatkan kerugian baik pada harta benda, lingkungan, maupun manusia (Budiono 2003). Penciptaan lingkungan kerja yang aman dapat dilakukan dengan mengidentifikasi potensi bahaya selama aktivitas penangkapan ikan berlangsung dan merencanakan teknik pengendaliannya sehingga mengurangi risiko yang timbul. Idealnya, kegiatan ini dilakukan pada tahap perencanaan kerja, namun pada penelitian ini identifikasi potensi bahaya dilakukan terhadap aktivitas yang sudah berlangsung dengan tujuan untuk mengevaluasi pekerjaan yang selama ini telah dilakukan.

Identifikasi potensi bahaya pada aktivitas penangkapan tuna di KM. Satelit dilakukan dengan metode JSA. Dalam penelitian ini, aktivitas yang dijabarkan dalam JSA hanyalah aktivitas penangkapan mulai dari setting, drifting, hauling, dan penanganan hasil tangkapan. Adapun aktivitas pelayaran menuju fishing ground, perjalanan menuju fishing ground lain, dan pelayaran kembali ke fishing base tidak dibahas. Data potensi bahaya, tingkat kemungkinan dan keparahan konsekuensinya diperoleh dari wawancara dengan semua ABK KM Satelit. Berdasarkan hasil analisis JSA (Tabel 5), terdapat 14 potensi bahaya yang mungkin timbul selama aktivitas penangkapan ikan dilakukan seperti yang ditujukkan pada Tabel 6 dan Gambar 3.

Gambar 3a memperlihatkan bahwa berdasarkan penilaian kemungkinan, potensi bahaya dengan kemungkinan "sering" mempunyai porsi terbesar dengan nilai $35,71 \%$. Potensi bahaya tersebut terdiri atas bahaya kebisingan, getaran, ergonomi, gerakan berulang, dan pengangkatan beban berat. Apabila dilihat tingkat konsekuensinya (Tabel 6), potensi bahaya yang sering dihadapi oleh ABK tersebut merupakan bahaya dengan konsekuensi hampir/tidak cidera hingga cidera ringan. Selanjutnya, berdasarkan Gambar 3b diketahui bahwa sebagian besar konsekuensi yang harus dihadapi oleh ABK adalah cidera berat $(28,57 \%)$ diikuti oleh cidera ringan dan kondisi fatal (masing-masing 21,43\%). 
Tabel 5 Job Safety Analysis

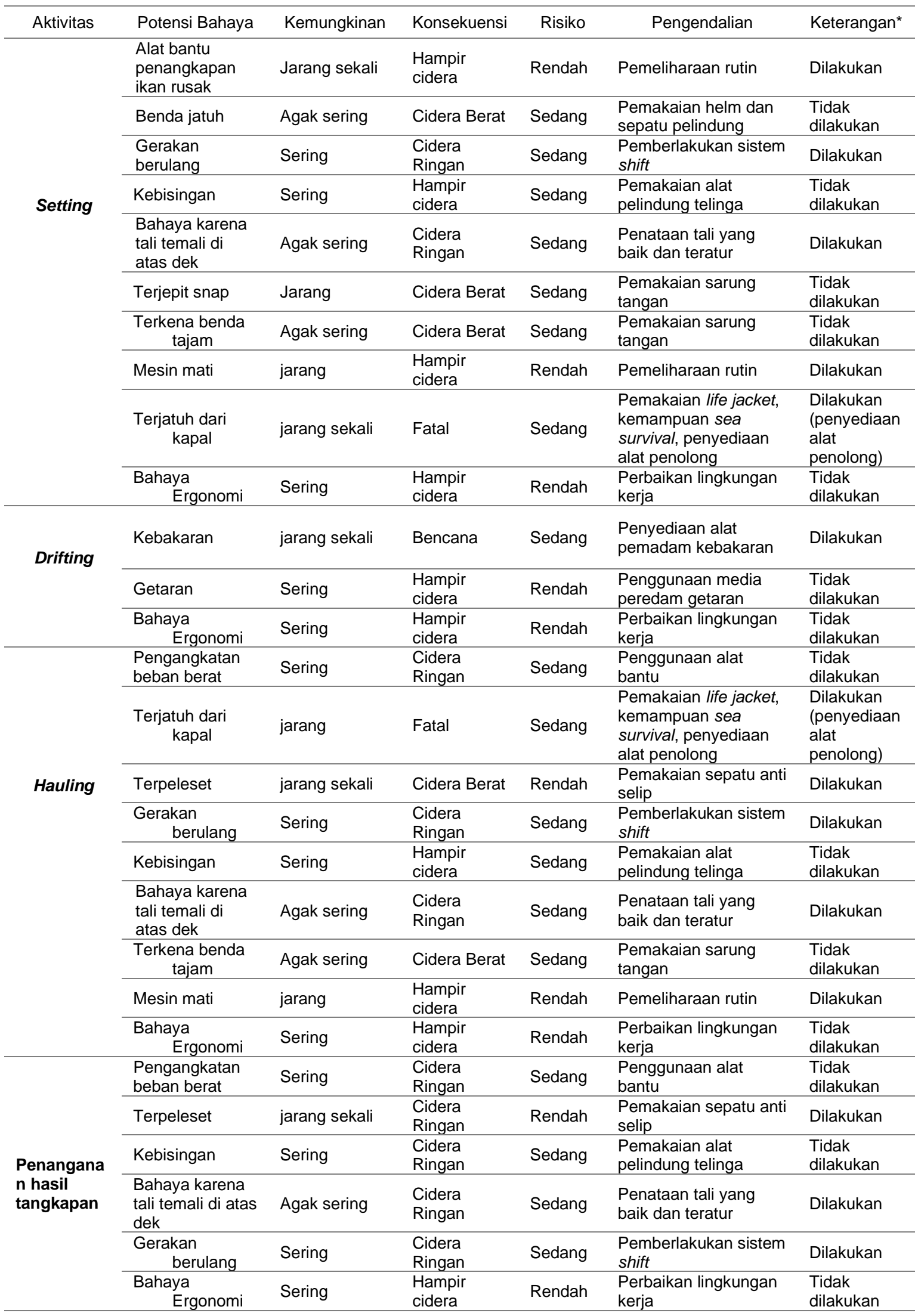


Tabel 6 Potensi Bahaya, Risiko dan Upaya Pengendalian pada Aktivitas Penangkapan Ikan Tuna KM. Satelit.

\begin{tabular}{|c|c|c|c|c|c|}
\hline No & Potensi Bahaya & $\begin{array}{c}\text { Kemungkin } \\
\text { an }\end{array}$ & Konsekuensi & Risiko & Tindakan Pencegahan \\
\hline 1 & $\begin{array}{l}\text { Alat bantu } \\
\text { penangkapan } \\
\text { ikan rusak }\end{array}$ & $\begin{array}{l}\text { Jarang } \\
\text { sekali }\end{array}$ & $\begin{array}{l}\text { Hampir/tidak } \\
\text { cidera }\end{array}$ & Rendah & Pemeliharaan rutin \\
\hline 2 & $\begin{array}{l}\text { Bahaya } \\
\text { Ergonomi }\end{array}$ & Sering & $\begin{array}{l}\text { Hampir/tidak } \\
\text { cidera }\end{array}$ & Rendah & Tidak ada \\
\hline 3 & $\begin{array}{l}\text { Bahaya karena } \\
\text { tali temali di atas } \\
\text { dek }\end{array}$ & $\begin{array}{l}\text { Agak } \\
\text { sering }\end{array}$ & Cidera Ringan & Sedang & $\begin{array}{l}\text { Penataan tali yang baik dan } \\
\text { teratur }\end{array}$ \\
\hline 4 & Benda jatuh & $\begin{array}{l}\text { Agak } \\
\text { sering }\end{array}$ & Cidera Berat & Sedang & Tidak ada \\
\hline 5 & $\begin{array}{l}\text { Gerakan } \\
\text { berulang }\end{array}$ & Sering & Cidera Ringan & Sedang & Pemberlakukan shif \\
\hline 6 & Getaran & Sering & $\begin{array}{l}\text { Hampir/tidak } \\
\text { cidera }\end{array}$ & Rendah & Tidak ada \\
\hline 7 & Kebakaran & $\begin{array}{l}\text { Jarang } \\
\text { sekali }\end{array}$ & Fatal & Sedang & $\begin{array}{l}\text { Penyediaan alat pemadam } \\
\text { kebakaran }\end{array}$ \\
\hline 8 & Kebisingan & Sering & $\begin{array}{l}\text { Hampir/tidak } \\
\text { cidera }\end{array}$ & Rendah & Tidak ada \\
\hline 9 & Mesin mati & Jarang & Fatal & Sedang & Pemeliharaan rutin \\
\hline 10 & $\begin{array}{l}\text { Pengangkatan } \\
\text { beban berat }\end{array}$ & Sering & Cidera Ringan & Sedang & Tidak ada \\
\hline 11 & $\begin{array}{l}\text { Terjatuh dari } \\
\text { kapal }\end{array}$ & $\begin{array}{l}\text { Jarang } \\
\text { sekali }\end{array}$ & Fatal & Sedang & Penyediaan alat penolong \\
\hline 12 & Terjepit snap & Jarang & Cidera Berat & Sedang & Tidak ada \\
\hline 13 & $\begin{array}{l}\text { Terkena benda } \\
\text { tajam }\end{array}$ & $\begin{array}{l}\text { Agak } \\
\text { sering }\end{array}$ & Cidera Berat & Sedang & Tidak ada \\
\hline 14 & Terpeleset & $\begin{array}{l}\text { Jarang } \\
\text { sekali }\end{array}$ & Cidera Berat & Rendah & Pemakaian sepatu anti selip \\
\hline
\end{tabular}
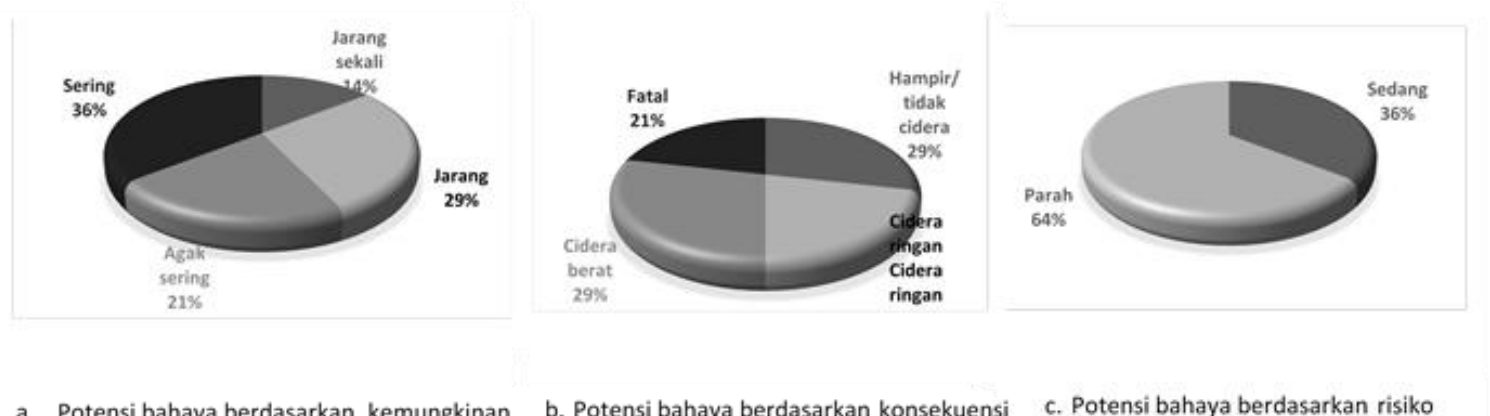

a. Potensi bahaya berdasarkan kemungkinan

b. Potensi bahaya berdasarkan konsekuensi

c. Potensi bahaya berdasarkan risiko

Gambar 3 Persentase potensi bahaya berdasarkan kemungkinan, konsekuensi dan risiko

\section{PEMBAHASAN}

Luasan area kerja di dek kapal sangat terbatas, yaitu antara $1-3 \mathrm{~m}^{2} /$ orang. Dalam area yang sempit tersebut, ABK tidak bebas bergerak. Tidak jarang mereka harus berdesakan, kaki saling menginjak, atau bahkan jatuh karena terdorong dan hilang keseimbangan. Selain itu, ketika waktu istirahat tiba, ABK tidak bisa terbebas dari kebisingan dan getaran ruang mesin. Kondisi lingkungan kerja yang tidak nyaman tersebut dapat mempercepat munculnya kelelahan yang pada akhirnya berimbas pada produktivitas kerja bahkan kecelakan kerja (Manuaba 2003, Dabholkar et al. 2014).

Menurut Suhadri (2008) terdapat 3 jenis kelelahan yang muncul setelah melakukan pekerjaan, yaitu kelelahan fisik, kelelahan patologis dan kelelahan psikologis. Namun, kelelahan yang dapat diidentifikasi selama penelitian ini berlangsung adalah kelelahan fisik dan kelelahan psikologis. Kelelahan fisik diakibatkan oleh kerja yang berlebihan dan pada umumnya dirasakan di 
daerah lengan/tangan, pinggang dan kaki. Hal ini dapat dipulihkan dalam dengan istirahat yang cukup. Sementara itu, kelelahan psikologis terjadi karena tekanan dan emosional yang terlalu tinggi. Medan kerja yang berat, lokasi yang monoton dan trip yang berbulan-bulan memicu terjadinya kelelahan ini. Kelelahan ini dipulihkan dengan menikmati sarana hiburan yang ada di atas kapal seperti televisi, DVD player dan bermain kartu.

Meskipun kondisinya sangat tidak nyaman, berdasarkan hasil penelitian, ABK tidak mengeluhkan hal tersebut. Semua responden menyatakan bahwa mereka merasa biasa saja dengan kondisi lingkungan kerjanya. Hal tersebut bukan disebabkan oleh tingkat toleransi mereka yang tinggi terhadap kondisi lingkungan kerja, tetapi lebih karena mereka tidak punya pilihan lain. Kondisi lingkungan kerja yang demikan bukan berarti tanpa risiko karena efeknya bisa muncul tanpa disadari oleh nelayan. Contohnya, seperti yang telah dinyatakan oleh Mansi et al. (2019) bahwa efek terpapar kebisingan dalam jangka waktu yang lama dan terus menerus dapat menimbulkan gangguan fisiologis dan psikologis. Selain itu, pengangkatan beban berat dan gerakan berulang, dapat menimbulkan kelelahan pada ABK yang pada akhirnya mempengaruhi produktivitas kerja mereka.

Benda-benda tajam (kail, ganco, pisau dan paku pembunuh), benda-benda berat yang jatuh ketika dibawa atau diletakkan di tempat yang tinggi (blong main line/brach line, hasil tangkapan, dan pelampung) serta ritme kerja yang cepat memunculkan risiko cidera berat yang dapat menyebabkan luka permanen atau bahkan kecacatan. Oleh karena penempatan alat dan alur kerja di atas kapal perlu diatur sedemikian hingga untuk meminimalkan risiko. Risiko lain yang dihadapi oleh nelayan adalah jatuh dari kapal yang dapat berakibat fatal. ABK yang bekerja di kapal KM Satelit umumnya adalah ABK yang masih minim pengalaman melautnya, bahkan tidak jarang mereka tidak pernah melaut sebelumnya, sehingga apabila mereka terjatuh dari kapal akan sangat fatal akibatnya. Kondisi fatal juga dapat diakibatkan dari kebakaran yang dapat ditimbul dari dapur ataupun ruang mesin. Dengan demikian, area ini harus bersih dari barangbarang yang mudah terbakar.

Berdasarkan tingkat risikonya, diketahui bahwa potensi bahaya dalam 64.35\% aktivitas penangkapan ikan tuna di KM Satelit masuk dalam kategori risiko sedang, sedangkan sisanya kategori risiko rendah. Di lain pihak, penelitian Suwardjo et al. (2010) mengungkapkan bahwa secara agregat tingkat kecelakaan kerja di kapal masuk dalam kategori unacceptable risk. Berdasarkan pernyataan tersebut, dapat dilihat bahwa hasil penelitian ini menjadi bertolak belakang. Hal ini disebabkan karena penelitian pada KM Satelit ini hanya fokus pada satu aktifitas saja, yaitu pengoperasian alat tangkap mulai dari setting hingga penangangan hasil tangkapan. Selain itu, objek penelitian ini juga terbatas pada satu kapal saja, tanpa memperhitungkan angka kecelakaan kerja dan akibat yang ditimbulkannya.

Berdasarkan identifikasi tindakan pencegahan yang selama ini dilakukan di KM Satelit, diketahui bahwa upaya pencegahan masih belum optimal. Sejauh ini, peralatan keselamatan yang disediakan hanya pelampung penolong dan pemadam kebakaran. Tidak terdapat satupun life jacket di atas kapal, begitu juga dengan pelindung seperti sarung tangan dan tutup telinga. Meskipun demikian, beberapa ABK telah terbiasa memakai sepatu anti selip pada saat bekerja.

\section{KESIMPULAN}

Berdasarkan penelitian ini, dapat disimpulkan beberapa hal berikut:

1. Analisis dari aspek ergonomi menunjukkan bahwa luasan area kerja di atas KM Satelit berkisar antara $1-3 \mathrm{~m}^{2} /$ orang, luasan tersebut masih sangat terbatas apabila mempertimbangkan aktivitas ABK selama bekerja. Selain itu, tata letak peralatan di atas dek juga belum sesuai dengan kondisi fisik ABK. Keterbatasan tersebut akan mempercepat timbulnya kelelahan bahkan kecelakaan kerja yang pada akhirnya mempengaruhi produktivitas kerja.

2. Analisis dari aspek keselamatan kerja menunjukkan bahwa terdapat 14 potensi bahaya yang timbul dari aktivitas penangkapan; 64,29\% dari potensi bahaya tersebut masuk dalam kategori risiko sedang dan 35,71\%-nya kategori risiko rendah. Meskipun demikian, belum ada upaya dari pemilik atau kapten kapal untuk mengoptimalkan tindakan pencegahan.

\section{SARAN}

Diperlukan penelitian dengan cakupan aktivitas dan jenis kapal yang lebih beragam 
agar dapat memberikan gambaran yang lebih komprehensif tentang ergonomi kapal penangkap ikan. Terkait dengan implementasi ergonomi pada kapal ikan, sosialisasi pada para pelaku usaha penangkapan ikan perlu dilakukan agar semakin tercipta kesadaran akan pentingnya aspek ini dalam meningkatkan keselamatan dan kenyamanan kerja di atas kapal.

\section{UCAPAN TERIMA KASIH}

Terima kasih disampaikan yang sebesar-besarnya kepada seluruh Crew KM Satelit yang telah membantu dalam proses pengambilan data.

\section{DAFTAR PUSTAKA}

Basya IF, Boesono H, Hapsari TD, 2017. Aspek Ergonomi pada Aktivitas Penangkapan Ikan Kapal Pancing Ulur di PPN Prigi Trenggalek. Juperta. 1 (2): $1-10$

Bayram M, Ünğan Mustafa, Ardıç K. 2016. The relationships between OHS prevention costs, safety performance, employee satisfaction and accident costs. International journal of occupational safety and ergonomics: JOSE.

23.

(10.1080/10803548.2016.1226607)

Budiono, S.A.M. 2003. Manajemen Resiko dalam Hiperkes dan Keselamatan Kerja Bunga Rampai Hiperkes dan KK. Edisi kedua Semarang: Universitas Diponegoro.

Dabholkar, T.A., Nakhawa, P., Yardi, S. 2014. Common musculoskeletal problems experienced by fishing industry workers. Indian Journal of Occupational and Environmental Medicine. 18(2): 4851. (Doi: 10.4103/0019-5278.146888)

Dharmawirawan DA dan Modjo R. 2012 Identifikasi Bahaya Keselamatan dan Kesehatan Kerja pada Penangkapan Ikan Nelayan Muroami. Kesmas. Jurnal Kesehatan Masyarakat Nasional. 6 (4): 185 - 192.

Deouskar N. 2017. The Impact of Ergonomics on the Productivity of People. International Journal of Marketing \& Financial Management. 5 (6): 59-63.
Duguid A, Vosper H. 2019. An Ergonomic Assessment of Small Boat Lobster. Eds. Charles $\mathrm{R}$ and Golightly $\mathrm{D}$. Proceedings of the International Conference on Ergonomics \& Human Factors 2019. Southampton: $7-10$ April 2019. United Kingdom

Fulmer, S., Buchholz, B. 2002. Ergonomics exposure case studies in Massachusetts fishing vessels. American Journal of Industrial Medicine Supplement. 2: 10-18. (Doi: 10.1002/ajim.10086)

Hutauruk RM, Lepinus T, Aryawan WD, Panunggal PE. 2011. Perancangan Tuna Longliner yang Efisien dan Optimum di Wilayah Perairan Bungus, Sumatera Barat. 219 -227. Prosiding Seminar Nasional Teknologi Kelautan.

Kolcaba, KY. 1992. Holistic Comfort: Operationalizing the Construct as $\mathrm{A}$ Nurse-Sensitive Outcome. Advances in Nursing Science. 15 (3): Hal 1 - 10.

Manuaba A. 2003. Holistic Ergonomic Design as a Strategy to Integrate Occupational Health - Safety System Management into the Enterprise Management System. 2nd NIEC (National Industrial Conference). Surabaya.

Mansi F, Cannone ESS, Caputi A, Maria Ld, Lella L, Cavone D and Vimercati L. 2019. Occupational Exposure on Board Fishing Vessels: Risk Assessments of Biomechanical Overload, Noise and Vibrations among Worker on Fishing Vessels in Southern Italy. Environment. 6 (127): 2 - 14.

Martino P, Rinawati D, and Rumita R. 2002. "Analisis Identifikasi Bahaya Kecelakaan Kerja Menggunakan Job Safety Analysis (JSA) Dengan Pendekatan Hazard Identification, Risk Assessment And Risk Control (HIRARC) di PT. Charoen Pokphand Indonesia- Semarang," Industrial Engineering Online Journal. 4 (2). [Online]

Marshall, S.W., Kucera, K., Loomis, D., McDonald, M.A., Lipscombe, H.J. 2004. Work related injuries in small scale commercial fishing. Injury Prevention. 10: 217-221.

Samara D., Sulistio J, Rachmawati M.R., Harrianto R. 2005. Sikap membungkuk dan Memutar Selama Bekerja sebagai 
Faktor Risiko Nyeri Punggung Bawah. Universa Medicina. 24 (3): 130 - 135

Soeboer DA, Imron Mohammad, Iskandar BI, Laksono MP. 2018. Aspek Ergonomi pada Aktivitas Penangkapan Ikan dengan Kapal Payang di

Palabuhanratu-Sukabumi. Albacore. 2 (3): 343 - 356

Suhadri B. 2008. Perancangan Sistem Kerja Dan Ergonomi 1. Jakarta: Direktorat Pembinaan Sekolah Menengah Kejuruan, Direktorat Jenderal Manajemen Pendidikan Dasar dan Menengah, Departemen Pendidikan Nasional.

Suwardjo, D. Haluan, J. Jaya, I. dan Poernomo, SH. 2010. Kajian Tingkat
Kecelakaan Fatal, Pencegahan dan Mitigasi Kecelakaan Kapal-Kapal Penangkap Ikan yang Beroperasi di PPP Tegalsari, PPN Pekalongan, dan PPS Cilacap. Jurnal Teknologi Perikanan \& Kelautan. 10 (1): 61 - 67.

Tarwaka. 2008. Keselamatan dan Kesehatan Kerja. Harapan Press: Surakarta.

Wignjosoebroto, S. 2000. Ergonomi, Studi Gerak dan Waktu: Teknik Analisis untuk Meningkatkan Produktivitas Kerja. Jakarta: PT. Gunawidya.

Wilson JR. 2000. Fundamentals of ergonomics in theory and practice. Applied Ergonomics. 31 (6): 557-567. (https://doi.org/10.1016/S00036870(00)00034-X). 